Journal of Economics and Behavioral Studies

Vol. 6, No. 4, pp. 318-332, Apr 2014 (ISSN: 2220-6140)

\title{
Is Universal Financial Education Putting the Cart Before the Horse?
}

\author{
Kathryn Simms \\ Old Dominion University, United States of America \\ ksimms@odu.edu
}

\begin{abstract}
This study evaluates the effectiveness of extant financial education in the United States (i.e., employer-provided education, financial education in high school, and financial education in college) via linear regression and logistic regression analyses conducted on data from the 2012 National Financial Capability Study (NFCS). It concludes that although formal financial education is associated with improved financial literacy above and beyond general educational attainment, employer-provided education and financial education in US high schools are frequently associated directly or indirectly with increased odds of an adverse personal financial event (i.e., foreclosure, bankruptcy, or being underwater). Financial education in college is either not significant or is indirectly associated with reduced odds of some these adverse events. Given these findings, it seems that generating and evaluating rigorous empirical evidence about effective methods and curriculums for teaching financial education should be an immediate policy priority rather than requiring universal financial education in haste. However, requiring universal financial education may be a worthy long-term goal, after these more immediate policy needs are achieved. These findings and recommendations contribute to the literature by helping to resolve relatively intense debate among researchers about the effectiveness of financial education via the first study that examines the efficacy of financial literacy in a nationally representative, US database.
\end{abstract}

Keywords: Financial literacy, financial education, US National Financial Capability Study, US economic and education policy, Great Recession

\section{Introduction}

More than $14.5 \%$ of residential properties in the US continue to be under water in the aftermath of the Great Recession (CoreLogic, 2013). About4.5 million home foreclosures have been completed in the US since September 2008 (CoreLogic, 2013), and over 7.3 million non-business US bankruptcies were filed from 2007 to 2012 (American Bankruptcy Institute [Abiworld], 2013). Although a variety of explanations have been suggested for this calamity in personal finances(Farmer, 2012; Jagannathan, Kapoor, \& Schhaumburg, 2013; Selmord, 2009), many policymakers have prescribed requiring universal financial education-which is largely centered on increasing financial literacy (i.e., personal financial knowledge and skills) — as a protective measure. In fact, former Chairman of the Federal Reserve, Ben Bernanke (2013), recently reiterated this endorsement "Among the lessons of the recent financial crisis is the need for virtually everyone-both young and old-to acquire a basic knowledge of finance and economics. Such knowledge is necessary for anyone who will be faced with managing a household budget, making financial investments, finding reliable information about buying a car or house, and preparing financially for retirement and other life goals. Accordingly, in addition to ensuring that students graduate with the financial literacy skills they need to navigate in the modern financial world, we, as a society, must also make sure that adults have opportunities to gain these skills or to refresh what they have learned [italics added]". (p. 2)

However, despite the former chairman's comments, controversy is rampant in the academic literature about the effectiveness of financial education in improving financial literacy. On one hand, research consistently detects relatively low levels of financial literacy in the United States (FINRA, 2013). It reports correlations between some proactive financial behaviors, such as saving for retirement (Lusardi \& Mitchell, 2011), and financial literacy. However, the case that supports financial education as an intervention for financial literacy is murky (Gale, Harris, \& Levine, 2012). In fact, much of the extant evidence fails to support financial education as a plausible intervention (Fernandes, Lynch \& Netemeyer, 2013). Other evidence is mixed (Miller, Reichelstein, Salas, \& Zia, 2014). This prior research has been based on meta-analyses (Fernandes et al., 2013; 
Miller et al., 2014), literature reviews (Willis, 2008), or single interventions (Mandell \& Klien, 2009). Hence, an important piece of evidence has been missing: Findings based on a nationally representative database that studies the effectiveness of naturally occurring financial education in the United States. This study fills this void in the literature by addressing the following research questions via the 2012 National Financial Capability Study:

Research Question 1: Does naturalistic financial education predict financial literacy in the United States?

Research Question 2: Does naturalistic financial education in the United States moderate financial literacy as a predictor of adverse events associated with the Great Recession of 2007-2009 (i.e., foreclosure, bankruptcy, and being "underwater")?

Research Question 3: Are there direct relationships among financial education in the United States and adverse events associated with the Great Recession of 2007-2009 (i.e., foreclosure, bankruptcy, and being "underwater")"?

The remainder of this article addresses these questions first by placing this study in context within the extant literature. Then, it describes the research methods used and study results. Finally, it discusses study findings, and offers conclusions and recommendations.

\section{Literature Review}

Advocates of financial education in the United States point to research that detect a positive correlation between measures of financial literacy and proactive financial behaviors such as retirement planning (Lusardi\& Mitchell, 2011) and increased savings (Miller et al., 2014). Additionally, lower financial literacy is significantly more common among those who have historically either been either disenfranchised or experienced social disparities in US society. More specifically, lower levels of financial literacy are associated with demographic factors such as being female (Lusardi \& Mitchell, 2008; Lusardi \& Mitchell, 2011), unmarried (Knoll, Tamborini \& Whitman, 2012), young (Lusardi, Mitchell \& Curto, 2010), less educated (Lusardi \& Mitchell, 2011), and African American or Hispanic (Lusardi \& Mitchell, 2011). Current educational policies, such as The No Child Left Behind Act (2002), are aimed at helping to ameliorate some of these disparities in US society by eliminating gaps in educational outcomes experienced by many of these groups. Hence, from a US policy perspective, a reasonable hypothesis would be that gaps in financial literacy among certain demographic groups can be eliminated through financial education.

This line of reasoning assumes that a positive causal link exists between formal financial education and (1) financial literacy and (2) the avoidance of adverse personal financial outcomes. It also assumes that it is possible to intervene to increase levels of financial literacy. In general, educational interventions in the United States are rarely successful (What Works Clearinghouse, 2014). Along these lines, recent studies suggest that there may be flaws in the logic that financial education enhances financial literacy, and, thus, prevents adverse financial events. Most recently, Fernandes et al. (2013) conducted a meta-analysis of 201 studies on the relationships among financial literacy, financial education, and financial behaviors. Intervention aimed at improving financial literacy accounted for only $0.1 \%$ of the variability in financial behaviors studied. Furthermore, the effectiveness of financial education dwindled away within 21 months. These results were considered so significant that The New York Times (Thaler, 2013) also published this information for general US readership. Fernandes et al.'s findings corroborate those of prior researchers such as Willis (2008) and Mandell and Klien (2009). However, until the current study, no nationally representative evidence has been available about the effectiveness of extant, naturalistic financial education in the United States.

\section{Methodology}

Data: All data for this study were derived from the public-use version of the 2012 National Financial Capability Study (NFCS). The FINRA Investor Education Foundation funded the NFCS and conceptualized this data-collection effort in collaboration with organizations such as The US Department of the Treasury and President Obama's Advisory Council on Financial Capability. The main objectives of the NFCS were to collect key benchmarks for assessing financial capability in the United States and to examine variability in these benchmarks. Applied Research and Consulting (ARC) was commissioned to collect the dataset through online surveys conducted from July to October 2012. ARC selected participants for these surveys based on a non- 
probability quota sampling technique through which NFCS participants were drawn from over a million participants in the Survey Sampling International, EMI Online Research Solutions, and Research Now. These three organizations validated participants' identities and self-reported demographics. The 25,509 adults who participated in NFCS were geographically distributed throughout the United States, with about 500 participants per state and the District of Columbia. Additionally, weights included in the dataset were applied to produce results that are representative of the US population in 2012 in terms of age, gender, ethnicity, education, and Census Division.

Measures: Each participant's financial literacy score was computed as the number of correct responses to five questions related to investing, borrowing, and personal financial management in the NFCS (Figure 1). Although the construct of financial literacy is not defined consistently in the literature (Huston, 2010; Knoll \& Houts, 2012; Schmeiser \& Seligman, 2013), measures similar to those in the NFCS have been well accepted in the literature (e.g., National Longitudinal Survey of Youth [Lusardi, Mitchell, \&Curto, 2010] and the 2004 US Health and Retirement [Lusardi \& Mitchell, 2011]). These measures have also been linked empirically to proactive financial behaviors such as retirement planning (Lusardi \& Mitchell, 2011).

Figure 1: Assessment of Financial Literacy in the 2012 National Financial Capability Study (NFCS)

1. Multiple Choice. Suppose you had $\$ 100$ in a savings account and the interest rate was $2 \%$ per year. After 5 years, how much do you think you would have in the account if you left the money to grow?

a. More than $\$ 102$ b. Exactly $\$ 102 \quad$ c. Less than $\$ 102$

(Answer: a.)

2. Multiple Choice. Imagine that the interest rate on your savings account was $1 \%$ per year and inflation was $2 \%$ per year. After 1 year, how much would you be able to buy with the money in this account?
a. More than today
b. Exactly the same c. Less than today

(Answer: c.)

3. Multiple Choice. If interest rates rise, what will typically happen to bond prices?
a. They will rise.
b. They will fall.
c. They will stay the same.

d. There is no relationship between bond prices and the interest rate.

(Answer: b.)

4. True or False. A 15-year mortgage typically requires higher monthly payments than a 30year mortgage, but the total interest paid over the life of the loan will be less.

(Answer: True.)

5. True or False. Buying a single company's stock usually provides a safer return than a stock mutual fund.

(Answer: False.)

Next, three binary variables-home foreclosure, declaring bankruptcy, and being "underwater" currently (i.e., owing more on a home mortgage that the house's resale value)-were computed from three corresponding questions in the dataset. NFCS questions on home foreclosure and declaring bankruptcy were based on whether either of these events had occurred during the last two years. Then, dummy variables were created that indicated the setting, if any, where participants reported having received financial education (i.e., high school, college, or employer-provided education). Because some participants had received financial education 
at more than one of these settings, a "counter" variable called "dosage" was also created. This variable tallied the number of settings in which each participant received a financial education. Additionally, a series of dummy variables indicated participants' highest level of educational attainment (i.e., some high school, high school diploma or GED, some college, undergraduate degree, or graduate degree). Furthermore, additional dummy variables served as covariates: gender, race, age, and marital status. A measure of risk-taking behavior was calculated based on participant's self-reported willingness to take risks when making financial investments. This measure ranged from 1 to 10 , where 1 indicated the lowest level of self-perceived risktaking and 10 indicated the highest level of such behavior. Finally, interactions between independent variables were created to test the explanatory power of the aspects of financial education described subsequently.

Analysis: After analyzing relevant descriptive statistics, I conducted multivariate linear regressions to evaluate whether either the setting or the dosage of financial education had explanatory power in predicting participants' financial literacy score. These regressions can be stated mathematically as follows:

Financial literacy ${ }_{\mathrm{i}}=b_{1}$ Education $_{\mathrm{i}}+\mathrm{b} 2$ Education $_{\mathrm{i}} *$ Setting $_{\mathrm{i}}+b_{3} *$ Gender $_{\mathrm{i}}+b_{4} *$ Race $_{\mathrm{i}}+b_{5} *$ Age $_{\mathrm{i}}+b_{6} *$ Marital status $_{\mathrm{i}}+$ $b_{0}+\varepsilon_{\mathrm{i},} \quad$ (equation 1)

and

Financial literacy $\mathrm{i}_{\mathrm{i}}=b_{1}$ Education $_{\mathrm{i}}+\mathrm{b} 2$ Dosage $_{\mathrm{i}}+b_{3} * \mathrm{Gender}_{\mathrm{i}}+b_{4} * \mathrm{Race}_{\mathrm{i}}+b_{5} *$ Age $_{\mathrm{i}}+b_{6} *$ Marital status $_{\mathrm{i}}+b_{0}+\varepsilon_{\mathrm{i}}$, (equation 2). Next, bivariate logistic regressions were used to evaluate whether either the setting or dosage of financial education moderated financial literacy in terms of predicting the odds of home foreclosure, declaring bankruptcy, or being "underwater." These logistic regressions can be stated mathematically as follows:

Ln $(\mathrm{p} /(1-\mathrm{p}))=b_{1}$ Financial Literacy $\mathrm{i}^{+} \quad b_{2}$ Financial Literacy ${ }_{\mathrm{i}}{ }^{*}$ Education $_{\mathrm{i}}+b_{3}{ }^{*}$ Risk-taking $_{\mathrm{i}}+b_{4}{ }^{*}$ Gender $_{\mathrm{i}}+b_{5}$ $*$ Race $_{\mathrm{i}}+b_{6}{ }^{*}$ Age $_{\mathrm{i}}+b_{7} *$ Marital status $\mathrm{i}+b_{0}+\varepsilon_{\mathrm{i}}$ (equation 3 )

and

Ln $(\mathrm{p} /(1-\mathrm{p}))=b_{1}$ Financial Literacy $\mathrm{i}_{\mathrm{i}}+b_{2}$ Financial Literacy ${ }_{\mathrm{i}}$ Dosage $_{\mathrm{i}}+b_{3} *$ Risk-taking $_{\mathrm{i}}+b_{4} *$ Gender $_{\mathrm{i}}+b_{5} *$ Race $_{\mathrm{i}}+$ $b_{6} *$ Age $_{\mathrm{i}}+b_{7} *$ Marital status $\mathrm{i}_{\mathrm{i}}+b_{0}+\varepsilon_{\mathrm{i}}$ (equation 4$)$.

Finally, bivariate logistic regressions were used to examine whether the setting or dosage of financial education directly predicted the odds of these three adverse financial events. These logistic regressions can be stated mathematically as follows:

Ln $(\mathrm{p} /(1-\mathrm{p}))=b_{1}$ Education $_{\mathrm{i}}+b_{2}$ Setting $_{\mathrm{i}}+b_{3} *$ Risk-taking $_{\mathrm{i}}+b_{4} *$ Gender $_{\mathrm{i}}+b_{5} *$ Race $_{\mathrm{i}}+b_{6} *$ Age $_{\mathrm{i}}+b_{7} *$ Marital status $_{\mathrm{i}}$ $+b_{0}+\varepsilon_{\mathrm{i},}$ (equation 5 )

and

Ln $(\mathrm{p} /(1-\mathrm{p}))=b_{1}$ Education $_{\mathrm{i}}+b_{2}$ Dosage $_{\mathrm{i}}+b_{3}{ }^{*}$ Risk-taking $_{\mathrm{i}}+b_{4}{ }^{*}$ Gender $_{\mathrm{i}}+b_{5} *$ Race $_{\mathrm{i}}+b_{6}{ }^{*}$ Age $_{\mathrm{i}}+b_{7} *$ Marital status $_{\mathrm{i}}$ $+b_{0}+\varepsilon_{\mathrm{i},}$ (equation 6).

All analyses were conducted on the full sample $(N=25,509)$, except for the analyses of currently being "underwater,"which I restricted to a subsample of homeowners $(n=14,727)$. Analyses were monitored carefully for any potential complications with multicollinearity. More specifically, Variance Inflations Factors (VIF) were required to be less than 5 in alignment with generally accepted practices. In the actual analysis, VIFs were always less than 4 , and $95 \%$ of the predictors (including all those related to main focal points of this study) had VIFs that were lower than 2.5 .

\section{Results}

Descriptive Statistics: Participants' mean score on the financial literacy assessment was about 58 on a 100point scale (Table 1), indicating that on average, most participants missed about two out of the five question. Mean scores by educational attainment ranged from $36 \%$ for those who had not completed high school to $75 \%$ for those who had completed a graduate degree in college. Of the participants, 954 had been involved in foreclosures on their homes during the last 2 years, and 904 had declared personal bankruptcy during the last 2 years. Despite similarities in the total number of people who had experienced these events, only 363 
people had experienced both of these financial events during the last 2 years. Additionally, 2,132 participants, or $14.5 \%$ of the homeowners, in the sample reported that they were currently underwater on their home mortgages. Furthermore, 2,630 (10\%) reported that they had received financial education in high school; $2,752(11 \%)$ reported that they had received financial education in college; and 2,241 (9\%) reported that they had received financial education from an employer. In terms of whether these participants had received financial education at more than one setting, 2,489 (10\%) reported that they had received financial education at only one of these settings, $1,574(6 \%)$ reported that they had received this education at two settings, and $662(2.6 \%)$ reported having received financial education at three settings. Table 1 provides additional descriptive statistics about the data, which are nationally representative of the U.S. population in terms of age, gender, ethnicity, education, and Census Division.

Table 1: Descriptive Statistics

\begin{tabular}{|c|c|c|}
\hline Measure & $N$ or $n$ & Percent or Mean (SD; Range) $^{a}$ \\
\hline \multicolumn{3}{|l|}{ Financial literacy score } \\
\hline Full sample & 25,509 & Mean: $57.56 \%$ (SD:29.3\%; Range 0 to $100 \%$ ) \\
\hline Some high school & 2,212 & Mean:36.21\%(SD:27.84\%;Range 0 to $100 \%)$ \\
\hline High school graduate & 7,513 & Mean:49.41\% (SD: $27.7 \%$; Range 0 to $100 \%$ ) \\
\hline Some college & 9,160 & Mean:60.64\% (SD: $27.6 \%$; Range 0 to $100 \%$ ) \\
\hline College: undergraduate degree & 4,105 & Mean:66.38\% (SD: $27.5 \%$; Range 0 to $100 \%$ ) \\
\hline College: graduate degree & 2,519 & Mean: $75.07 \%$ (SD:26.2\%; Range 0 to $100 \%$ ) \\
\hline $\begin{array}{l}\text { Involved in foreclosure on home in the last } 2 \\
\text { years }\end{array}$ & 954 & $3.7 \%$ \\
\hline Declared bankruptcy in the last 2 years & 904 & $3.5 \%$ \\
\hline $\begin{array}{l}\text { Both declared bankruptcy and involved in } \\
\text { foreclosure on home in the last } 2 \text { years }\end{array}$ & 363 & $1.4 \%$ \\
\hline Home owners & 14,727 & $57.7 \%$ \\
\hline Currently underwater on home mortgage & 2,132 & $\begin{array}{l}14.5 \% \text { ( } \% \text { homeowners underwater relative } \\
\text { to all homeowners) }\end{array}$ \\
\hline Female & 13,117 & $51.4 \%$ \\
\hline Male & 12,392 & $48.6 \%$ \\
\hline White & 16,956 & $66.5 \%$ \\
\hline Not White & 8,553 & $33.5 \%$ \\
\hline $18-24$ & 3,139 & $12.3 \%$ \\
\hline Older than $18-24$ & 22,370 & $87.7 \%$ \\
\hline Married & 13,782 & $54.0 \%$ \\
\hline Living with partner & 2,080 & $8.2 \%$ \\
\hline Single & 9,647 & $37.8 \%$ \\
\hline \multicolumn{3}{|l|}{ Highest level of education: } \\
\hline Some high school & 2,212 & $8.7 \%$ \\
\hline High school graduate & 7,513 & $29.5 \%$ \\
\hline Some college & 9,160 & $35.9 \%$ \\
\hline College: undergraduate degree & 4,105 & $16.1 \%$ \\
\hline College: graduate degree & 2,519 & $9.8 \%$ \\
\hline Self-perceived level of risk-taking & 25,509 & Mean: 4.84 (SD: 2.6;Range: 1 low to 10 high) \\
\hline Received financial education in high schoolb & 2,630 & $10.3 \%$ \\
\hline Received financial education in collegec & 2,752 & $10.8 \%$ \\
\hline Received financial education from employer & 2,241 & $8.8 \%$ \\
\hline
\end{tabular}




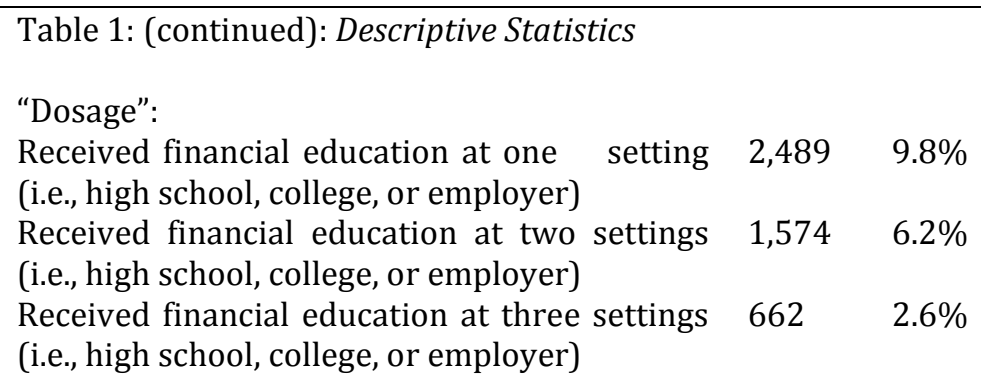

Notes: National-level weights were applied so that the analysis is nationally representative of the US population in terms of age, gender, ethnicity, education, and Census Division. aThis column provides the percentage of participants relative to (1) the total sample (or, if stated, relative to a subsample) or (2) the mean and range of the data. ${ }^{b}$ Of those who received financial education in high school, 129 did not graduate from high school, 620 graduated from high school only, 1075 completed some college, 487 completed their undergraduate degrees (only), and 319 completed postgraduate degrees. ${ }^{\mathrm{c} O f}$ those whoreceived financial education in college, 1,186 attended but did not complete college, 948 completed their undergraduate degrees, and 618 completed postgraduate degrees.

Financial Education as a Predictor of Financial Literacy: Table 2 provides results of regressions used to evaluate the association between the setting and dosage of financial education and financial literacy controlled for educational attainment and the demographic covariates shown. In eight out of nine cases, financial education setting had significant explanatory power in predicting participants' financial literacy scores above and beyond educational attainment. For example, regression analysis indicated that participants who did not completed high school scored about 27-points lower on the financial literacy assessment than did participants who had completed college, where scores were expressed on a scale from 0 to 100 -points. However, participants who had had some financial education in high school, but had not did not complete high school scored about 15-points higher in comparison with participants who completed high school nor had financial education in high school. On the whole, financial education-including employer-provided financial education-was associated with higher scores on the financial literacy assessment. An exception was that participants who had both graduate degrees and financial education in high school were predicted to score 4-point lower on the literacy assessment than participants who had graduate degrees, but no financial education in high school. Additionally, having an undergraduate degree and a financial education in high school was not associated with significant differences in financial literacy compared to those with an undergraduate degree, but no financial education in high school. By contrast, having financial education in college was associated with improved scores for those had completed some college (2-points), an undergraduate degree (6-points), and a graduate degree (5-points). Effect sizes related to financial education, measured as standardized coefficients, ranged from .02 to .05 .

Having had a financial education in one, two, or three settings was associated with 6- to 9-points higher financial literacy scores compared to not having had financial education. In supplemental analyses, reference categories for dosage were rotated to test the explanatory power of all possible patterns of dosage. Only, 2dosages in lieu of 3-dosages of financial literacy was significant, and was associated with a 3-point increase in literacy scores ( $p=.03$ ).Effect sizes for significant measures of dosage ranged from .02 to .07 . Additionally, despite controls for financial education and educational attainment, female participants tended to underperform relative to male participants by about 9-points; white participants outperformed non-white participants by about 9-points; participants who were ages18-24 underperformed compared to older participants by 11-points; and married participants outperformed single participants by about 5-points. Effect sizes for significant demographic variables ranged from .09 to .15. 
Table 2: Linear Regression: Education as a Predictor of Financial Literacy $(\mathrm{N}=\mathbf{2 5 , 5 0 9 )}$

\begin{tabular}{|c|c|c|}
\hline Measure & $\begin{array}{l}\text { Regression 1: }{ }^{\mathrm{a}} \\
\text { Setting } \\
\text { Unstandardized Coefficient } \\
\text { SE } \\
\text { Standardized Coefficient }\end{array}$ & $\begin{array}{l}\text { Regression 2:b } \\
\text { Dosage } \\
\text { Unstandardized Coefficient } \\
\text { SE } \\
\text { Standardized Coefficient }\end{array}$ \\
\hline \multicolumn{3}{|l|}{ Highest level of education: } \\
\hline Some high school & $\begin{array}{l}-27.392^{* * *} \\
.750 \\
-.263\end{array}$ & $\begin{array}{l}-26.871^{* * *} \\
.711 \\
-.258\end{array}$ \\
\hline High school graduate & $\begin{array}{l}-15.524^{* * *} \\
.565 \\
-.241\end{array}$ & $\begin{array}{l}-15.399 * * * \\
.518 \\
-.239\end{array}$ \\
\hline Some college & $\begin{array}{l}-4.573^{* * *} \\
.554 \\
-.075\end{array}$ & $\begin{array}{l}-5.049 * * * \\
.493 \\
-.083\end{array}$ \\
\hline College: undergraduate degree & - & - \\
\hline College: graduate degree & $\begin{array}{l}7.227^{\text {*** }} \\
.758 \\
.074\end{array}$ & $\begin{array}{l}6.493^{* * *} \\
.660 \\
.066\end{array}$ \\
\hline Interactions: $^{\mathrm{d}}$ & & \\
\hline $\begin{array}{l}\text { Financial education in high school } \mathrm{X} \\
\text { some high school education }\end{array}$ & $\begin{array}{l}14.677^{* * *} \\
2.366 \\
.036\end{array}$ & $\mathrm{n} / \mathrm{a}$ \\
\hline $\begin{array}{l}\text { Financial education in high school } \mathrm{X} \\
\text { high school completed }\end{array}$ & $\begin{array}{l}7.665^{* * *} \\
1.109 \\
.040\end{array}$ & $\mathrm{n} / \mathrm{a}$ \\
\hline $\begin{array}{l}\text { Financial education in high school } \mathrm{X} \\
\text { some college }\end{array}$ & $\begin{array}{l}2.498^{*} \\
.968 \\
.017\end{array}$ & $\mathrm{n} / \mathrm{a}$ \\
\hline $\begin{array}{l}\text { Financial education in high school } \mathrm{X} \\
\text { undergraduate degree }\end{array}$ & $\begin{array}{l}-.872 \\
1.484 \\
-.004\end{array}$ & $\mathrm{n} / \mathrm{a}$ \\
\hline $\begin{array}{l}\text { Financial education in high school } \mathrm{X} \\
\text { graduate degree }\end{array}$ & $\begin{array}{l}-4.099 * \\
1.861 \\
-.016\end{array}$ & $\mathrm{n} / \mathrm{a}$ \\
\hline $\begin{array}{l}\text { Financial education in college } \mathrm{X} \text { some } \\
\text { college }\end{array}$ & $\begin{array}{l}2.082^{*} \\
.925 \\
.015\end{array}$ & $\mathrm{n} / \mathrm{a}$ \\
\hline $\begin{array}{l}\text { Financial education in college } \mathrm{X} \\
\text { undergraduate degree }\end{array}$ & $\begin{array}{l}6.346^{* * *} \\
1.155 \\
.041\end{array}$ & $\mathrm{n} / \mathrm{a}$ \\
\hline $\begin{array}{l}\text { Financial education in college } \mathrm{X} \\
\text { graduate degree }\end{array}$ & $\begin{array}{l}4.854^{* *} \\
1.461 \\
.025\end{array}$ & $\mathrm{n} / \mathrm{a}$ \\
\hline
\end{tabular}


Table 2: (continued): Linear Regression: Education as a Predictor of Financial Literacy $(\mathrm{N}=\mathbf{2 5}, 509)$

\begin{tabular}{|c|c|c|}
\hline Measure & $\begin{array}{l}\text { Regression } 1:^{a} \\
\text { Setting } \\
\text { Unstandardized } \\
\text { Coefficient } \\
\text { SE } \\
\text { Standardized Coefficient }\end{array}$ & $\begin{array}{l}\text { Regression } 2: \mathrm{b} \\
\text { Dosage } \\
\text { Unstandardized } \\
\text { Coefficient } \\
\text { SE } \\
\text { Standardized Coefficient }\end{array}$ \\
\hline $\begin{array}{lll}\text { Employer } & \text { provided financial } \\
\text { education } & & \end{array}$ & $\begin{array}{l}5.125^{* * *} \\
.665 \\
.049\end{array}$ & $\mathrm{n} / \mathrm{a}$ \\
\hline $\begin{array}{l}\text { Dosage: } \\
\text { Received no financial education at any } \\
\text { setting }^{c}\end{array}$ & $\mathrm{n} / \mathrm{a}$ & - \\
\hline $\begin{array}{l}\text { Received financial education at one } \\
\text { setting (i.e., high school, college, or } \\
\text { employer) }\end{array}$ & $\mathrm{n} / \mathrm{a}$ & $\begin{array}{l}7.246^{* * *} \\
.556 \\
.073\end{array}$ \\
\hline $\begin{array}{l}\text { Received financial education at two } \\
\text { settings (i.e., high school, college, or } \\
\text { employer) }\end{array}$ & $\mathrm{n} / \mathrm{a}$ & $\begin{array}{l}8.622^{* * *} \\
.691 \\
.071\end{array}$ \\
\hline $\begin{array}{l}\text { Received financial education at three } \\
\text { settings (i.e., high school, college, or } \\
\text { employer) }\end{array}$ & $\mathrm{n} / \mathrm{a}$ & $\begin{array}{l}6.006^{* * *} \\
1.040 \\
.033\end{array}$ \\
\hline $\begin{array}{l}\text { Covariates: } \\
\text { Female }\end{array}$ & $\begin{array}{l}-8.810^{* * *} \\
.328 \\
-.150\end{array}$ & $\begin{array}{l}-8.847^{* * *} \\
.328 \\
-.151\end{array}$ \\
\hline $\begin{array}{l}\text { Malec } \\
\text { White }\end{array}$ & $\begin{array}{l}- \\
9.002^{* * *} \\
.355 \\
.145\end{array}$ & $\begin{array}{l}- \\
8.973^{* * *} \\
.355 \\
.145\end{array}$ \\
\hline $\begin{array}{l}\text { Not whitec } \\
18-24\end{array}$ & $\begin{array}{l}-11.233^{* * *} \\
.529 \\
-.126\end{array}$ & $\begin{array}{l}-11.341^{* * *} \\
.527 \\
-.127\end{array}$ \\
\hline Older than $18-24^{c}$ & - & - \\
\hline Married & $\begin{array}{l}4.986^{* * *} \\
.362 \\
.085\end{array}$ & $\begin{array}{l}5.037^{* * *} \\
.362 \\
.086\end{array}$ \\
\hline Living with partner & $\begin{array}{l}-.334 \\
.630 \\
-.003\end{array}$ & $\begin{array}{l}-.262 \\
.630 \\
-.002\end{array}$ \\
\hline Single ${ }^{c}$ & - & - \\
\hline Constant & $\begin{array}{l}61.501^{* * *} \\
.577 \\
-\end{array}$ & $\begin{array}{l}61.484^{* * *} \\
.542 \\
-\end{array}$ \\
\hline $\mathrm{R}^{2}$ & .213 & .213 \\
\hline
\end{tabular}

Notes: National-level weights were applied so that the analysis is nationally representative of the U.S. population in terms of age, gender, ethnicity, education, and Census Division. For ease of interpretation,

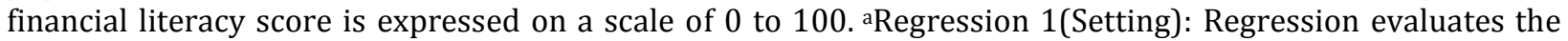
explanatory power of the setting of financial education (i.e., high school, college, or employment). ${ }^{b}$ Regression 2 (Dosage): Regression evaluates the explanatory power of the "dosage" of education (i.e., number of settings in which financial education occurred, where settings included high school, college, or employment.) cReference category (excluded from regression). dinteraction between setting of financial education and educational attainment. ${ }^{*} p<.05 ;{ }^{* *} p<.01 ;{ }^{* *} p<.001$ 
Financial Education as a Moderator of Financial Literacy in Predicting Foreclosure, Bankruptcy, or Being "Underwater": Table 3 provides the results of logistic regressions that tested the explanatory power of the setting of financial education as a moderator of financial literacy in predicting foreclosure, bankruptcy, or being "underwater." These analyses were controlled for self-perceived risk-taking and the demographic covariates shown. Dosage of financial education was not a significant moderator of financial literacy in any case, and, therefore, results for dosage are not provided in Table 3 in the interest of space. Among those with no financial education in any setting, answering one additional question on the financial literacy assessment correctly was associated with about $23 \%$ reduced odds of foreclosure and bankruptcy, and about $16 \%$ reduced odds of being underwater. Having a financial education in any setting was not a significant moderator of financial literacy in terms of being "underwater." In contrast, answering one additional question on the financial literacy assessment correctly was associated with $16 \%$ reduced odds of foreclosure among those who had had a financial education in high school (i.e., $7 \%$ worse odds than not having a financial education); and with $14 \%$ reduced odds among those who had an employer-provided financial education (i.e., $9 \%$ worse odds compared with having no financial education). Among those who had a financial education in college, the odds of foreclosure were reduced by $31 \%$ for each additional question the participant answered correctly (i.e., $8 \%$ better odds than not having a financial education). Among those who had financial education in high school and college, one additional correct answer on the financial literacy assessment reduced the odds of bankruptcy around $29 \%$ (i.e., $6 \%$ better odds of not declaring bankruptcy compared to not having a financial education). Level of educational attainment was not a significant predictor of any of the adverse financial events in this series of logistic regressions. Furthermore, financial literacy and the moderator relationships tested did not explain the significance of "demographic gaps" in increased odds of experiencing an adverse financial event. Greater self-perceived risk-taking investment behavior, being male, not being white, and being married/living with a partner were typically associated with greater odds of experiencing each event.

Table 3: Financial Education as a Moderator to Financial Literacy in Predicting Foreclosure, Bankruptcy, or Being "Underwater"

\begin{tabular}{|c|c|c|c|}
\hline Measure & $\begin{array}{l}\text { Regression 1: } \\
\text { Foreclosure } \\
\text { B } \\
\text { Odds ratio } \\
\text { SE (B) }\end{array}$ & $\begin{array}{l}\text { Regression 2: } \\
\text { Bankruptcy } \\
\text { B } \\
\text { Odds ratio } \\
\text { SE(B) } \\
\end{array}$ & $\begin{array}{l}\text { Regression 3:a } \\
\text { Underwater } \\
\text { B } \\
\text { Odds ratio } \\
\text { SE(B) } \\
\end{array}$ \\
\hline \multirow[t]{3}{*}{ Financial literacy score ${ }^{b}$} & $-.263^{* * *}$ & $-.271^{* * *}$ & $-.173^{* * *}$ \\
\hline & .768 & .763 & .842 \\
\hline & .025 & .026 & .108 \\
\hline \multirow{3}{*}{$\begin{array}{l}\text { Score }{ }^{b} \mathrm{X} \text { high school financial } \\
\text { education }\end{array}$} & $.084^{*}$ & $-.089 *$ & .034 \\
\hline & 1.088 & 1.093 & 1.034 \\
\hline & .037 & .039 & .025 \\
\hline \multirow[t]{3}{*}{ Score $^{\mathrm{b}} \mathrm{X}$ college financial education } & $-.113^{* *}$ & $-.085^{*}$ & -.024 \\
\hline & .893 & .918 & .976 \\
\hline & .039 & .041 & .025 \\
\hline X employer-provided & $.113^{* *}$ & .068 & .007 \\
\hline \multirow{2}{*}{ financial education } & 1.120 & 1.070 & 1.007 \\
\hline & .036 & .039 & .024 \\
\hline Score X no financial educationc & - & - & - \\
\hline \multicolumn{4}{|l|}{ Highest level of education: } \\
\hline \multirow[t]{3}{*}{ Some high school } & -.286 & -.076 & -.187 \\
\hline & .751 & .927 & .829 \\
\hline & .152 & .149 & .127 \\
\hline \multirow[t]{3}{*}{ High school graduate } & -.109 & -.042 & -.017 \\
\hline & .897 & .959 & .983 \\
\hline & .106 & .111 & .075 \\
\hline \multirow[t]{3}{*}{ Some college } & -.185 & -.092 & 0 \\
\hline & .831 & .912 & 1.000 \\
\hline & .101 & .106 & .068 \\
\hline
\end{tabular}




\begin{tabular}{llll}
\hline College: undergraduate degree & & - & - \\
College: graduate degree & .181 & .158 & -.076 \\
& 1.199 & 1.171 & .926 \\
& .125 & .134 & .088 \\
Covariates: & & & \\
Risk-taking & $.151^{* * *}$ & $.078^{* * *}$ & $.034^{* * *}$ \\
& 1.163 & 1.081 & 1.034 \\
Female & .013 & .013 & .009 \\
& $-.454^{* * *}$ & $-.322^{* * *}$ & $-.188^{* * *}$ \\
Malec & .635 & .724 & .829 \\
White & .071 & .071 & .050 \\
& - & - & - \\
Not white & $-.298^{* * *}$ & $-.253^{* * *}$ & $-.543^{* * *}$ \\
18-24 & .743 & .777 & .581 \\
& .070 & .073 & .502 \\
Older than $18-24^{\mathrm{b}}$ & - & - & - \\
& .102 & .008 & $.292^{* *}$ \\
& .1 .107 & 1.008 & .339 \\
\hline
\end{tabular}

Table 3: (Continued): Financial Education as a Moderator to Financial Literacy in Predicting Foreclosure, Bankruptcy, or Being "Underwater"

\begin{tabular}{clll}
\hline & $\begin{array}{l}\text { Regression 1: } \\
\text { Foreclosure }\end{array}$ & $\begin{array}{l}\text { Regression 2: } \\
\text { Bankruptcy }\end{array}$ & $\begin{array}{l}\text { Regression 3:a } \\
\text { Underwater }\end{array}$ \\
& B & B & B \\
Odds ratio & Odds ratio & $\begin{array}{l}\text { Odds ratio } \\
\text { SE(B) }\end{array}$ \\
\hline Measure & SE (B) & SE(B) & $.292^{* * *}$ \\
& $.281^{* * *}$ & $.485^{* * *}$ & 1.339 \\
Larried & 1.324 & 1.624 & .509 \\
& .076 & .080 & $.212^{*}$ \\
Living with partner & .124 & $.419^{* *}$ & 1.236 \\
Singlec & 1.132 & 1.520 & .106 \\
Constant & .128 & .126 & - \\
& - & - & $1.159^{* * *}$ \\
& $-3.076^{* * *}$ & -2.969 & .314 \\
\hline
\end{tabular}

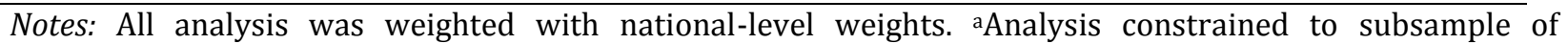
homeowners $(n=14,727)$; other analyses were based on the full sample $(N=25,509)$. bFinancial literacy score is expressed in terms of number of questions ( 0 to 5 ) answered correctly. CReference category (excluded from regression). ${ }^{*} p<.05 ;{ }^{* *} p<.01 ;{ }^{* * *} p<.001$

The Direct Relationships among Financial Education and Foreclosure, Bankruptcy, or Being "Underwater": Table 4 presents the results of logistic regressions that tested the direct relationship of setting and dosage of financial education in predicting foreclosure, bankruptcy, and being "underwater." Analyses were controlled for level of educational attainment, self-perceived risk-taking, and the demographic covariates shown. Having had a financial education in high school and completing high school was associated with $73 \%$ higher odds of home foreclosure, $65 \%$ higher odds of bankruptcy, and 38\% greater odds of being underwater. Having a graduate degree and also having completed financial education in high school was associated with $82 \%$ greater odds of foreclosure. Having received employer-provided financial education was associated with $75 \%$ higher odds of foreclosure and $43 \%$ higher odds of bankruptcy. Additionally, receiving a financial education in three settings compared with no settings was associated with $93 \%$ higher odds of declaring bankruptcy and $43 \%$ higher odds being underwater. Whereas, the odds of foreclosure were $23 \%$ 
higher, $29 \%$ higher, and $119 \%$ higher when participants received one, two, or three dosages of financial education, respectively, compared to no financial education. Level of educational attainment had little significant explanatory power in this series of regressions. The only consistent relationship detected was that not completing high school was associated with having about $46-47 \%$ higher odds of bankruptcy. Financial education did not explain the significance of demographic patterns related to the increased likelihood of experiencing these three adverse financial events. Typically, participants who were prone to taking higher risks, male, non-white, younger (ages 18-24), and married had greater odds of encountering each negative financial event.

Table 4: Bivariate Logistic Regression: Financial Education as a Predictor of Home Foreclosure, Declaring Bankruptcy, or Being "Underwater"

\begin{tabular}{|c|c|c|c|c|c|c|}
\hline Measure & $\begin{array}{l}\text { Settinga } \\
\text { Foreclosure } \\
\text { B } \\
\text { Odds ratio } \\
\text { SE(B) }\end{array}$ & $\begin{array}{l}\text { Bankruptcy } \\
\text { B } \\
\text { Odds ratio } \\
\text { SE(B) }\end{array}$ & $\begin{array}{l}\text { Underwater } \\
\text { B } \\
\text { Odds ratio } \\
\text { SE(B) }\end{array}$ & $\begin{array}{l}\text { Dosageb }^{\mathbf{b}} \\
\text { Foreclosure } \\
\text { B } \\
\text { Odds ratio } \\
\text { SE(B) }\end{array}$ & $\begin{array}{l}\text { Bankruptcy } \\
\text { B } \\
\text { Odds ratio } \\
\text { SE(B) }\end{array}$ & $\begin{array}{l}\text { Underwater } \\
\text { B } \\
\text { Odds ratio } \\
\text { SE(B) }\end{array}$ \\
\hline \multicolumn{7}{|l|}{$\begin{array}{l}\text { Highest level of } \\
\text { education: }\end{array}$} \\
\hline Some high school & $\begin{array}{r}.150 \\
1.162 \\
.158\end{array}$ & $\begin{array}{c}.384^{*} \\
1.468 \\
.154\end{array}$ & $\begin{array}{l}.092 \\
1.097 \\
.128\end{array}$ & $\begin{array}{l}.196 \\
1.216 \\
.149\end{array}$ & $\begin{array}{l}.376^{*} \\
1.456 \\
.146\end{array}$ & $\begin{array}{l}.053 \\
1.055 \\
.125\end{array}$ \\
\hline High school graduate & $\begin{array}{r}.083 \\
1.087 \\
.116\end{array}$ & $\begin{array}{r}.162 \\
1.176 \\
.120\end{array}$ & $\begin{array}{l}.072 \\
1.075 \\
.079\end{array}$ & $\begin{array}{c}.224^{*} \\
1.251 \\
.104\end{array}$ & $\begin{array}{c}.254^{*} \\
1.289 \\
.109\end{array}$ & $\begin{array}{l}.140 \\
1.151 \\
.073\end{array}$ \\
\hline Some college & $\begin{array}{r}-.095 \\
.909 \\
.114\end{array}$ & $\begin{array}{r}-.006 \\
.994 \\
.119\end{array}$ & $\begin{array}{l}.029 \\
1.030 \\
.076\end{array}$ & $\begin{array}{r}-.055 \\
.946 \\
.100\end{array}$ & $\begin{array}{r}.019 \\
1.019 \\
.105\end{array}$ & $\begin{array}{l}.046 \\
1.047 \\
.068\end{array}$ \\
\hline $\begin{array}{l}\text { College: } \\
\text { undergraduate } \\
\text { degree }^{c}\end{array}$ & - & - & - & - & - & - \\
\hline $\begin{array}{l}\text { College: graduate } \\
\text { degree }\end{array}$ & $\begin{array}{l}.091 \\
1.095 \\
.146\end{array}$ & $\begin{array}{l}.120 \\
1.128 \\
.154\end{array}$ & $\begin{array}{l}-.196 \\
.822 \\
.102\end{array}$ & $\begin{array}{r}.111 \\
1.118 \\
.124\end{array}$ & $\begin{array}{r}.080 \\
1.083 \\
.134\end{array}$ & $\begin{array}{l}-.130 \\
.878 \\
.087\end{array}$ \\
\hline Interactions: & & & & & & \\
\hline $\begin{array}{l}\text { Financial education in } \\
\text { high school } X \text { some }\end{array}$ & $\begin{aligned}-.113 \\
.893\end{aligned}$ & $\begin{array}{r}-.647 \\
.524\end{array}$ & $\begin{array}{l}-2.312 \\
.099\end{array}$ & & & \\
\hline high school education & .472 & .585 & 1.218 & $\mathrm{n} / \mathrm{a}$ & $\mathrm{n} / \mathrm{a}$ & $\mathrm{n} / \mathrm{a}$ \\
\hline $\begin{array}{l}\text { Financial education in } \\
\text { high school } X \text { high }\end{array}$ & $\begin{array}{l}.549^{* *} \\
1.731\end{array}$ & $\begin{array}{l}.498^{* *} \\
1.645\end{array}$ & $\begin{array}{l}.324^{*} \\
1.383\end{array}$ & & & \\
\hline $\begin{array}{ll}\text { school education } \\
\text { completed }\end{array}$ & .173 & .183 & .145 & $\mathrm{n} / \mathrm{a}$ & $\mathrm{n} / \mathrm{a}$ & $\mathrm{n} / \mathrm{a}$ \\
\hline Financial education in & .006 & .266 & -.064 & & & \\
\hline high school X some & 1.006 & 1.304 & .938 & & & \\
\hline college & .193 & .192 & .142 & $n / a$ & $\mathrm{n} / \mathrm{a}$ & $\mathrm{n} / \mathrm{a}$ \\
\hline Financial education in & .338 & .219 & .303 & & & \\
\hline high school X & 1.403 & 1.245 & 1.354 & & & \\
\hline undergraduate degree & .261 & .286 & .188 & $\mathrm{n} / \mathrm{a}$ & $\mathrm{n} / \mathrm{a}$ & $\mathrm{n} / \mathrm{a}$ \\
\hline Financial education in & $.601 *$ & .299 & .043 & & & \\
\hline high school X graduate & $\begin{array}{r}1.823 \\
299\end{array}$ & $\begin{array}{r}1.349 \\
355\end{array}$ & $\begin{array}{l}1.048 \\
232\end{array}$ & $n /$ & $n / a$ & $n /$ \\
\hline
\end{tabular}


Table 4: (Continued) Bivariate Logistic Regression: Financial Education as a Predictor of Home Foreclosure, Declaring Bankruptcy, or Being "Underwater"

\begin{tabular}{|c|c|c|c|c|c|c|}
\hline Measure & $\begin{array}{l}\text { Settinga } \\
\text { Foreclosure } \\
\text { B } \\
\text { Odds ratio } \\
\text { SE(B) }\end{array}$ & $\begin{array}{l}\text { Bankruptcy } \\
\text { B } \\
\text { Odds ratio } \\
\text { SE(B) }\end{array}$ & $\begin{array}{l}\text { Underwater } \\
\text { B } \\
\text { Odds ratio } \\
\text { SE(B) }\end{array}$ & $\begin{array}{l}\text { Dosage } \\
\text { Foreclosure } \\
\text { B } \\
\text { Odds ratio } \\
\text { SE(B) }\end{array}$ & $\begin{array}{l}\text { Bankruptcy } \\
\text { B } \\
\text { Odds ratio } \\
\text { SE(B) }\end{array}$ & $\begin{array}{l}\text { Underwater } \\
\text { B } \\
\text { Odds ratio } \\
\text { SE(B) }\end{array}$ \\
\hline Financial education in & -.340 & -1.87 & -.298 & & & \\
\hline college $\quad X$ & .711 & .830 & .742 & & & \\
\hline undergraduate degree & .227 & .240 & .160 & $\mathrm{n} / \mathrm{a}$ & $\mathrm{n} / \mathrm{a}$ & $\mathrm{n} / \mathrm{a}$ \\
\hline Financial education in & -.486 & -.432 & .082 & & & \\
\hline college $\mathrm{X}$ graduate & 615 & .649 & 1.086 & & & \\
\hline degree & .269 & .300 & 186 & $\mathrm{n} / \mathrm{a}$ & $\mathrm{n} / \mathrm{a}$ & $\mathrm{n} / \mathrm{a}$ \\
\hline Employer-provided & $.557^{* * *}$ & $.359 * *$ & .128 & & & \\
\hline financial education & 1.746 & 1.433 & 1.136 & & & \\
\hline & .112 & .123 & .086 & $\mathrm{n} / \mathrm{a}$ & $\mathrm{n} / \mathrm{a}$ & $\mathrm{n} / \mathrm{a}$ \\
\hline $\begin{array}{l}\text { Dosage: } \\
\text { Received no financial } \\
\text { education at any } \\
\text { settingc }\end{array}$ & $n / a$ & $\mathrm{n} / \mathrm{a}$ & $\mathrm{n} / \mathrm{a}$ & - & - & - \\
\hline $\begin{array}{l}\text { Received financial } \\
\text { education at one }\end{array}$ & & & & $\begin{array}{c}.210^{*} \\
1.234\end{array}$ & $\begin{array}{r}.175 \\
1.191\end{array}$ & $\begin{array}{l}-.132 \\
.876\end{array}$ \\
\hline $\begin{array}{l}\text { setting (i.e., high } \\
\text { school, college, or } \\
\text { employer) }\end{array}$ & $\mathrm{n} / \mathrm{a}$ & $\mathrm{n} / \mathrm{a}$ & $\mathrm{n} / \mathrm{a}$ & .106 & .110 & .083 \\
\hline Received financial & & & & $.251^{*}$ & -.002 & -.021 \\
\hline education at two & & & & 1.286 & .998 & .979 \\
\hline $\begin{array}{l}\text { settings (i.e., high } \\
\text { school, college, or } \\
\text { employer) }\end{array}$ & $\mathrm{n} / \mathrm{a}$ & $\mathrm{n} / \mathrm{a}$ & $\mathrm{n} / \mathrm{a}$ & .125 & .144 & .093 \\
\hline Received financial & & & & $.785^{* * *}$ & $.659^{* * *}$ & $.355^{* *}$ \\
\hline education at three & & & & 2.192 & 1.933 & 1.426 \\
\hline $\begin{array}{l}\text { settings (i.e., high } \\
\text { school, college, or } \\
\text { employer) }\end{array}$ & $\mathrm{n} / \mathrm{a}$ & $\mathrm{n} / \mathrm{a}$ & $\mathrm{n} / \mathrm{a}$ & .152 & .167 & .118 \\
\hline \multicolumn{7}{|l|}{ Covariates: } \\
\hline \multirow[t]{3}{*}{ Risk-taking } & $.149^{* * *}$ & $.076^{* * *}$ & $.031^{* *}$ & $.150^{* * *}$ & $.076^{* * *}$ & $.032^{* *}$ \\
\hline & 1.160 & 1.079 & 1.032 & 1.162 & 1.079 & 1.032 \\
\hline & .013 & .013 & .009 & .130 & .013 & .009 \\
\hline \multirow[t]{3}{*}{ Female } & $-.335^{* * *}$ & $-.204^{* *}$ & $-.114^{*}$ & $-.338^{* * *}$ & $-.206^{* *}$ & $-.115^{*}$ \\
\hline & .715 & .816 & .892 & .713 & .814 & .891 \\
\hline & .070 & .070 & .049 & .070 & .070 & .049 \\
\hline
\end{tabular}

Table 4: (Continued) Bivariate Logistic Regression: Education as a Predictor of Home Foreclosure, Declaring Bankruptcy, or Being "Underwater"

\begin{tabular}{cllllll}
\hline & Setting & & & Dosage $^{\mathrm{b}}$ & & \\
& Foreclosure & Bankruptcy & Underwater & Foreclosure & Bankruptcy & Underwater \\
& $\mathrm{B}$ & $\mathrm{B}$ & $\mathrm{B}$ & $\mathrm{B}$ & $\mathrm{B}$ & $\mathrm{B}$ \\
Measure & Odds ratio & Odds ratio & Odds ratio & Odds ratio & Odds ratio & Odds ratio \\
\hline Male & $\mathrm{SE}(\mathrm{B})$ & $\mathrm{SE}(\mathrm{B})$ & $\mathrm{SE}(\mathrm{B})$ & $\mathrm{SE}(\mathrm{B})$ & $\mathrm{SE}(\mathrm{B})$ & $\mathrm{SE}(\mathrm{B})$ \\
White & - & - & - & - & - & - \\
& $-.412^{* * *}$ & $-.372^{* * *}$ & $.612^{* * *}$ & $-.417^{* * *}$ & $-.373^{* * *}$ & $-.615^{* * *}$ \\
& .662 & .689 & .542 & .659 & .689 & .541 \\
& .069 & .072 & .051 & .069 & .071 & .051
\end{tabular}




\begin{tabular}{|c|c|c|c|c|c|c|}
\hline Not whitec & - & - & - & - & - & - \\
\hline \multirow[t]{3}{*}{$18-24$} & $.235^{*}$ & .152 & $.436^{* * *}$ & $.233^{*}$ & .153 & $.458^{* * *}$ \\
\hline & 1.265 & 1.164 & 1.547 & 1.262 & 1.165 & 1.581 \\
\hline & .101 & .107 & .099 & . 100 & .107 & .098 \\
\hline Older than $18-24 \mathrm{c}$ & - & - & - & - & - & - \\
\hline \multirow[t]{3}{*}{ Married } & $.221^{* *}$ & $.419^{* * *}$ & $.253^{* * *}$ & $.228^{* *}$ & $.426^{* * *}$ & $.254^{* * *}$ \\
\hline & 1.247 & 1.520 & 1.287 & 1.257 & 1.531 & 1.289 \\
\hline & .076 & .080 & .058 & .076 & .080 & .058 \\
\hline \multirow[t]{3}{*}{ Living with partner } & .098 & $.400^{* *}$ & .184 & .111 & $.410^{* *}$ & 190 \\
\hline & 1.103 & 1.492 & 1.203 & 1.118 & 1.506 & 1.209 \\
\hline & .128 & .126 & 106 & .128 & .125 & 106 \\
\hline Singlec $^{c}$ & - & - & - & - & - & - \\
\hline \multirow[t]{3}{*}{ Constant } & $-3.896^{* * *}$ & $-3.791^{* * *}$ & $-1.694^{* * *}$ & $-3.966^{* * *}$ & $-3.828^{* * *}$ & $-.1711^{* * *}$ \\
\hline & .020 & .023 & .184 & .019 & .022 & .181 \\
\hline & .146 & .149 & .102 & .140 & .143 & .099 \\
\hline
\end{tabular}

Notes: Analysis was weighted with national-level weights but, in the case of being "underwater," was also constrained to subsample of homeowners $(n=14,727)$; other analyses were based on the full sample $(N=$ 25,509). aSetting: Regression assesses the explanatory power of the setting of financial education (i.e., high school, college, or employment). bDosage: Regression assesses the explanatory power of the "dosage" of education (i.e., number of settings in which financial education occurred, where settings are high school, college, or employment.) cReference category (excluded from regression). dInteraction between setting of financial education and highest degree of education. ${ }^{*} p<.05 ;{ }^{* *} p<.01 ;{ }^{* * *} p<.001$

Discussion: In some respects, this study supports conventional wisdom: Relatively little formal financial education appears to take place in the United States. In fact, only about 1 in 10 participants in the 2012 NFCS reported that they had received financial education in either high school, in college, or at their place of employment. This study also provides additional empirical evidence that corroborates widely perceived demographic disparities in financial literacy. On the other hand, this study does not support an immediate initiative for universal financial education as a panacea for overcoming demographic disparities in financial literacy or for preventing personal financial calamities associated with the Great Recession. All analyses detected that significant demographic disparities remained in the presence of extant financial education. Consequently, current formal opportunities for financial education do not appear to explain demographic disparities in financial literacy or in higher odds of experiencing an adverse personal financial event. Results do suggest that extant financial education bolsters financial literacy above and beyond general educational attainment, without alleviating demographic disparities. Important caveats emerge about financial education in high school among persons with higher levels of educational attainment. Financial education in high school does not appear to improve the financial literacy of those who earn undergraduate degrees in college, and it may be counterproductive to those who earn graduate degrees. The immediate difficulty of addressing this caveat in practice is that we cannot conclusively predict in advance which high school students will later graduate from college, much less which ones will go on to earn graduate degrees.

Moreover, financial literacy sometimes had no predictive power as a moderator of financial literacy in reducing the odds of the adverse financial event studied (i.e., foreclosure, bankruptcy, and being "underwater"). Only financial education in college was consistently associated with a lower likelihood of experiencing one of these adverse financial events, when financial education in college was a significant moderator of financial literacy. Here, the protective effects of a financial education were modest (i.e., $8 \%$ reduced odds foreclosure and $6 \%$ reduced odds of bankruptcy). Having a financial education in high school was associated with modest protection in the case of bankruptcy, but with adverse effectiveness in the case of foreclosure. Employer-provided education was significantly associated with increased odds of home foreclosure. The direct effects of extant formal financial education were also disconcerting. Participants who completed high school and also had financial education in high school had higher odds of undergoing foreclosure, declaring bankruptcy, and being underwater. Participants with a graduate degree who had also had financial education in high school were $82 \%$ more likely to experience home foreclosure. Having received employer-provided financial education was associated with increased odds of experiencing foreclosure and bankruptcy. The direct effect of having a financial education in college was not significantly associated with 
the odds of foreclosure, bankruptcy, or being "underwater." A subcomponent of this study examined dosage-or the number of times participants had financial education independent of setting-as an explanatory factor. However, findings indicate that dosage is not a particularly meaningful measure. Relatively few of the results related to dosage were significant. Those that were may have been masked by adverse results detected about financial education in high school and employer-provided financial education and by more positive results about financial education in college. It seems likely that setting is probably the more relevant measure.

Questions remain about what explains study findings. In other words, how can extant formal financial education be associated with improved financial literacy, yet have few positive (and even negative) implications for preventing foreclosure, bankruptcy, and being underwater? It is possible that this finding may have occurred because these financial events are highly complex, and financial education (on the whole) may not be successful in teaching the higher-order thinking skills or the advanced content knowledge necessary to deal with these highly challenging events. In fact, as a result of their general levels of educational attainment, many of those who complete college or graduate school may be overconfident about their abilities to apply their more basic high school financial educations to real life. Furthermore, many of the protective factors associated with financial literacy and with demographic disparities may arise as the result of informal social learning opportunities. Just as with any study, the findings reported here should be evaluated in conjunction with the limitations in the research design. Such limitations include those that are always associated with regression analysis (e.g., lack of causality), and surveys approaches to data collection (e.g., self-reported data). Several limitations are also specific to this study. First, detailed data about participants' financial educations were not available. Hence, course content and length are not known. Presumably, some participants mastered the material, and other participants did not understand it all on any level. Yet, no data were available to control for these likely differences in achievement. Additionally, no information was available about why some participants decided to repeat financial education in more than one setting. Some participants may have gained knowledge in the prior setting and been seeking additional skills. Other participants might have been seeking more education because they were experiencing personal financial difficulties. Hence, the examination of dosage might have inadvertently introduced a selection bias toward identifying participants who had higher odds of personal financial difficulty. Furthermore, this study's cross-sectional design precludes an assessment of variability in participants' financial behaviors over time. This limitation arises from an inherent limitation in the data: During the first wave of NFCS in 2009, participants were not asked questions about their prior financial educations, and the participants were not the same across data waves. This lack of longitudinal data cannot be addressed via another dataset at this time because the 2012 wave of the NFCS is the first to offer nationally representative data about participants' financial educations. Finally, it would be ideal to replicate this study in another sample.

\section{Conclusion and Recommendations}

The findings of this study do not necessarily preclude the implementation of universal financial education in the long run. Instead, policies that call for implementing financial education immediately may be premature. Immediate policy priorities should include rigorous, empirical evaluations that determine curriculum and effective methods for teaching financial education. The implementations of such policies might proceed in the following fashion:

- Identify a national panel of experts in financial education at the K-12, college, and employer levels.

- Charge this group of experts with developing a registry of empirically corroborated "Best Practices" for financial education instruction at the K-12, college, and employer levels.

- Develop an empirically corroborated curriculum at each education level based on these "Best Practices."

- Pilot test these curriculums and improve them as needed.

- Evaluate the effectiveness of these curriculums as they are scaled up gradually to a national level.

- Without such policy initiatives, this study suggests that financial education that is mainly low-impact or associated with adverse personal outcomes may be replicated among larger segments of the U.S. population. Additionally, it seems that studying what is inside the "black box" of financial education in high school may be an urgent priority. 


\section{References}

Abiworld. (2013). Bankruptcy Filings 1980-2012. Retrieved from http://www.abiworld.org/AM/AMTemplate.cfm?Section=Home\&TEMPLATE=/CM/ContentDisplay.c fm\&CONTENTID $=66471$.

Bernanke, B. S. (2013). Financial and economic education speech at the 13th annual redefining investment strategy education (RISE) forum, Dayton, Ohio (via prerecorded video). Retrieved from http://www.federalreserve.gov/newsevents/speech/20130404a.htm

CoreLogic. (2013). CoreLogic Reports 2.5M more residential properties return to positive equity in second quarter of 2013. Retrieved from http://www.corelogic.com/about-us/news/corelogic-reports-2.5million-more-residential-properties-return-to-positive-equity-in-second-quarter-of-2013.aspx.

Farmer, R. E. (2012). The stock market crash of 2008 caused the Great Recession: Theory and evidence. Journal of Economic Dynamics \& Control, 36(5), 693-707.

Fernandes, D., Lynch, J. G. \& Netemeyer, R.G. (2013) Financial literacy, financial education and downstream financial behaviors, Management Science [published online before print]Permalink: http://dx.doi.org/10.1287/mnsc.2013.1849.

FINRA Investor Education Foundation. (2013). Financial Capability in the United States: Report of Findings from the 2012 National Financial Capability Study. Retrieved from http://www.usfinancialcapability.org/downloads/NFCS_2012_Report_Natl_Findings.pdf

Gale, W. G. Harris, B. H. \& Levine, R. (2012). Raising Household savings: Does financial education work? Social Security Bulletin, 72(2), 39-48.

Huston, S. J. (2010). Measuring Financial Literacy. The Journal of Consumer Affairs, 44(2), 296-316.

Jagannathan, R. Mudit K. \& Schhaumburg, E. (2013). Causes of the Great Recession of 2007-2009: The financial crisis was the symptom not the disease! Journal of Financial Intermediation, 22(1), 4-29.

Knoll, M. A. \& Houts, C. R. (2012). The financial knowledge scale: An application of item response theory to the assessment of financial literacy. The Journal of Consumer Affairs, 46(3), 381-410.

Knoll, M. A., Tamborini, C. R. \& Whitman, K. (2012). I do ... want to save: Marriage and retirement savings in young households. Journal of Marriage and Family, 74(2), 86-100.

Lusardi, A. \& Mitchell, O. S. (2008). Planning and financial literacy: How do women fare? American Economic Review: Papers \& Proceedings, 98(2), 413-417.

Lusardi, A. \& Mitchell, O. S. (2011). Financial literacy around the world: An overview. Journal of Pension Economics and Finance, 10(4), 497-508.

Lusardi, A., Mitchell, O. S. \& Curto, V. (2010). Financial literacy among the young. The Journal of Consumer Affairs, 44(2), 358-380.

Mandell, L. \& Klein, L. S. (2009). The impact of financial literacy education on subsequent financial behavior. Journal of Financial Counseling and Planning, 20(1), 15-24.

Miller, M., Reichelstein, J., Salas, C. \& Zia, B. (2014). Can you help someone become financially capable? A meta-analysis of the literature. The World Bank Development Research Group, Policy Research Working Paper 6745. Retrieved from http://econ.worldbank.org/WBSITE/EXTERNAL/EXTDEC /EXTRESEARCH/0,,contentMDK:23513927 pagePK:64165401 piPK:64165026 theSitePK:469382 ,00.html

No Child Left Behind Act of 2001. (2002). Pub.L. 107-110, 115 Stat. 1425.

Thaler, R. H. (2013). Financial Literacy, Beyond the Classroom. The New York Times retrieved from http://www.nytimes.com/2013/10/06/business/financial-literacy-beyond-the-classroom.html? pagewanted=all\&_r $=0$

Schmeiser, M. D. \& Seligman, J. S. (2013). Using the right yardstick: Assessing financial literacy measures by way of financial well-being. The Journal of Consumer Affairs, 47(2), 243-262.

Selmord, J. (2009). Lessons for tax policy in the Great Recession. National Tax Journal, 63(3), 387-397.

What Works Clearinghouse. (2014). United States Department of Education: Institute of Educational Sciences. Retrieved from http://ies.ed.gov/ncee/wwc/default.aspx

Willis, L. E. (2008). Against financial literacy education. University of Pennsylvania Law School Public Law \& Legal Theory Research Paper No. 8-10 and Loyal University Law School, Los Angles Legal Studies $\begin{array}{lllll}\text { Research } & \text { paper } & \text { No. } & \text { Re } & \text { from }\end{array}$ http://papers.ssrn.com/sol3/papers.cfm?abstract_id=1105384. 